$$
\text { "tmcs-konya-report" — 2012/3/1 — 18:29 — page 205 — \#1 }
$$

\title{
Report of Meeting Researches in Didactics of Mathematics and Computer Sciences January 20 - January 22, 2012, Levocă, Slovakia
}

\author{
Compiled by E. Herendiné KónYA
}

\begin{abstract}
The meeting Researches in Didactics of Mathematics and Computer Sciences was held in Levocă, Slovakia from the 20th to the 22th of January, 2012. The 66 participants - including 54 lecturers and $25 \mathrm{PhD}$ students - came from 6 countries, 20 cities and represented 33 institutions of higher and secondary education. The abstract of the talks and the posters and also the list of participants are presented in this report.

Key words and phrases: new methods in teaching, experiments in teaching, talent care, history of mathematics, geometry and its practical applications, the use of computers in teaching mathematics.
\end{abstract}

ZDM Subject Classification: A60.

The meeting Researches in Didactics of Mathematics and Computer Sciences was held in Levocă, Slovakia from the 20th to the 22th of January, 2012 at the Juraj Páleš Institute in Levocă, Faculty of Education of the Catholic University in Ružomberok. It was organized by the PhD School of Mathematics and Computer Sciences of the University of Debrecen, Debrecen Reformed Theological University, Kölcsey Ferenc Institute of Primary Education, and the Juraj Páleš Institute in Levocă, Faculty of Education of the Catholic University of Ružomberok. The meeting was supported by the CEEPUS III Exchange Programme for University Studies, and the projects:

- KEGA 001UJS-4/2011 Podpora výučby matematiky pomocou vol'ne dostupných matematických softvérov

Copyright (c) 2012 by University of Debrecen 


$$
\text { "tmcs-konya-report" — 2012/3/1 — 18:29 — page 206 — \#2 }
$$

- TAMOP-4.22/B/10/1-2010-0024.

The 66 participants - including 54 lecturers and $25 \mathrm{PhD}$ students - came from 6 countries, 20 cities and represented 33 intstitutions of higher education.

After the warm welcome of professor Amantius Akimjak, the vice-dean of the Faculty of Education of the Catholic University in Ružomberok, the conference was opened by professor Zsolt Páles, vice-rector of the University of Debrecen, leader of the PhD School of Mathematics and Computer Sciences. He welcomed the participants and emphasized the importance of the fact that the conference was held this year at a new location, in Slovakia.

The subjects presented in the lectures and posters of the conference were of great variety. Beyond the researches on the history of mathematics, geometry, didactics of mathematics, the use of alternative methods in teaching mathematics, there were several lectures on different subjects in computer sciences.

A very memorable event of the meeting was the sightseeing in the historical centre of Levocă.

In his closing speech, professor Gyula Maksa, leader of the Didactic Program of the PhD School of Mathematics and Computer Sciences appreciated the high quality of the lectures, with special regard to the works of the invited lecturers and $\mathrm{PhD}$ students. He also gave his thanks to all the lecturers, the chairs of sessions, and also to the main organizers Eszter Herendiné Kónya PhD and Ján Gunčaga $\mathrm{PhD}$, whose work essentially contributed to the success of the conference.

Subsequently, we provide the abstracts of the lectures in alphabetical order, followed by the names and contact data of the authors.

\section{List of abstracts of lectures}

The role of Working memory in the teaching of word problems András Ambrus - Ilona Máté

Eötvös Lorand University, Mathematics Teaching and Education Centre, Budapest, Hungary

$$
\text { E-mail: ambrus@cs.elte.hu }
$$

In our talk we will present the first results of a class experiment. The investigated sixth grade class students have met first time systematically with solving word problems. The main aim of our experiment was to find the failures, problems relating the Working memory of children and give help to remedy them. We will analyse the relevant problems in the teaching process, and compare the results 


$$
\text { "tmcs-konya-report" — 2012/3/1 — 18:29 — page } 207 \text { — \#3 }
$$

of the pre test and post test, and draw some consequences for the mathematics teaching practice.

Basic trigonometric formulas in an inquiring approach

$$
\text { Szilárd András }
$$

Babeş-Bolyai University, Faculty of Mathematics and Informatics, Cluj-Napoca,

$$
\text { Romania }
$$

E-mail: andraszk@yahoo.com

The main aim of this paper is to present an inquiry based professional development activity about the teaching of basic trigonometric relations and some conclusions about possible implementations in the framework of regular school lessons. The activity itself was designed to understand basic facts about the structure and the construction of standard curricula parts and in the same time to achieve a higher consciousness level in choosing teaching attitudes.

The pitfalls of fake analogy: the favourable relation and implication

$$
\text { Viktor Bakos }
$$

Budapest Business School, College of International Management and Business,

$$
\text { Budapest, Hungary }
$$

E-mail: Bakos.Viktor@kkfk.bgf.hu

This paper deals with the topic of a peculiar relation of (random) events, namely the favourable relation, a special case of which is implication. This paper presents some of its important features, its most interesting adaptations and its role played in the interpretation of paradoxes (Simpson paradox), which can be originated in the fact that it behaves totally differently than implication.

Furthermore, this paper highlights the relationship between the topics of decomposition (or standardization) that are well known in statistics - can be assigned to József Körösy - and the above relation. Based on all the above, this paper presents some further ideas how and where this favourable relation can be placed in mathematics education

For what's enough 14 weeks?

Tünde Baranyai

Babeş-Bolyai University, Faculty of Psychology and Educational Sciences, Satu

Mare, Romania

E-mail: baratun@yahoo.com

The classes of mathematics and other majors decreased significantly into the Romanian Primary School and Kindergarten Teacher Training Colleges after 


$$
\text { "tmcs-konya-report" — 2012/3/1 — 18:29 — page } 208 \text { — \#4 }
$$

introduction the bologna process into the higher education. Therefore the teachers have only 14 weeks to prepare the students with the level of knowledge that is necessary for the teaching of mathematics. Our research presents a comparative analysis of the results between the third year full time students and the third year distance students.

Talented pupils in maths and the use of cooperative techniques - the plan of an experiment

$$
\text { Krisztina Barczi }
$$

Neumann János High School, Eger, Hungary

$$
\text { E-mail: bkrixta@gmail.com }
$$

Why talented pupils and cooperative techniques? Nowadays innovative ways of teaching are becoming more and more widespread in Hungary. One of the most popular methods is cooperative teaching techniques that are shown to be effective by many studies and experiments. Originally the idea of cooperative learning was to help the learning and improvement of children with sociocultural disadvantages and who usually underachieve. Besides helping underachievers to catch up, working with talented pupils is a priority in education. That is why the question what the effect of regular use of cooperative teaching would be on pupils who are gifted and talented in Mathematics arises. The presentation discusses the plan of an experiment that was designed to answer these questions.

\section{Adaptation of informatics in teaching algebra \\ Judit Boda}

University of Debrecen, Institute of Earth Sciences, Debrecen, Hungary

$$
\text { E-mail: boda.judit@science.unideb.hu }
$$

Since term of 2010/2011 I am a maths teacher in the Ferenc Kölcsey Grammar School in Debrecen. Due to being a night school the students' content is mixed because for attending to this school as adults there are several reasons. I knew the challenge of teaching there is different as in other high schools. My aim is to review my collected experience of teaching the topic 'Algebra and quadratic equation' and those handouts and instructional aides which were devised by me for maths lessons during the last and 2011/2012 semester. The students needed to have regular practice to acquire terms of algebra and get at good solutions of different tasks. For this reason I made two programs. Due to these programs my work became more effective and faster. Through these I can generate utility tasks and give them to students for homework. The hang of solution can be 


$$
\text { "tmcs-konya-report" — 2012/3/1 — 18:29 — page } 209 \text { — \#5 }
$$

also generated by these programs so the checking can be simple. Through these exercises I can encourage my students for regular learning and practice. My experience shows that the students like this subject better and better and they solve the tasks more confidently.

\section{Examination of combinatory skill in lower primary school Ignác Bontovics}

Szent István University, Fakulty of Applied Arts and Pedagogy, Szarvas,

$$
\text { Hungary }
$$

E-mail: bignacz@gmail.com

Number of basic examples of combinatory can be met in lower primary school. I am looking for the answer the question that how easy to write on the second and third combinations of five elements. This question is interesting for me because of more things. One of these, in both cases the same kinds of possibilities are. The other is born of experience rather. When ask people about which is easier: 5 hit from 90 or 85 hit from 90 , then the second version is signed by them firstly. In turn, in both cases, such as also previously, the number of possibilities is the same. I created a flash animation for the research, where the steps of students were recorded. I wish to describe the results and experiences of these steps.

\section{Developing disadvantaged students with GeoGebra László Budai \\ II. Rákóczi Ferenc Secondary School, Szécsény, Hungary E-mail: budai0912@gmail.com}

According to the tendency of the past 15 years, the number of students in primary schools is decreasing nationwide. Parallel to this, the number of disadvantaged students is increasing, exceeding one third of all students. This greatly affects students' value and behaviour brought into school. It is extremely difficult in case of these students to find a way that would lead to the development of selfmotivation not only in the field of Mathematics but also that of general approach to studying. Within this, GeoGebra as a dynamic geometric system has proved to be very effective when developing disadvantaged students.

I would introduce my observations in reflection of the past three years (20082011): the viewpoint for me was not only describing cognitive qualities quantitatively but I also emphasized the affective and psychomotoric factors. 


$$
\text { "tmcs-konya-report" — 2012/3/1 — 18:29 — page 210 — \#6 }
$$

Results of mathematics "Test zero" at Budapest University of Technology and Economics in 2011 Anikó Csákány

Budapest University of Technology and Economics, Institute of Mathematics, Budapest, Hungary

E-mail: csakany@math.bme.hu

It is essential for higher education institutions to implement strategies or steps to improve the teaching methods used in mathematics sessions, so as to subsequently reduce the problem of non-completion. In order to decrease the number of failures and drop-outs Budapest University of Technology and Economics (BME), among several other Hungarian universities, introduced new pilot projects in mathematics. As one element of these steps freshmen admitted by the BME are required to take a test, called "test zero" in mathematics since 2009.

This paper pictures the story of mathematics "test zero". The 2011 results of all 3300 participants are presented and attention is called to typical mistakes and typical test taking strategies of students. Some of the most important and interesting conclusions are highlighted.

\author{
How we teach Mathematics? \\ Edith Debrenti \\ Partium Christian University, Oradea, Romania \\ E-mail: edit.debrenti@gmail.com
}

The secondary school teaching plays an important role in the development of the problem solving skills and of the knowledge needed to acquire these skills. It also has a great influence upon the ability of acquiring specific knowledge required in the high education (at the university) of subjects at the Faculty of Economics such as economic mathematics, economic statistics, calculation of probability, accounting, etc. I carried out a survey among the first year students in economy regarding the methods they had met in practice while learning. I wished to find out:

- how often did they use the problem centered methods as well as the experience based and analytic methods or other methods reveling different alternatives

- which is their attitude towards mathematics

- what are their previous experiences

- what are their competitions in modelling and practicing 


$$
\text { "tmcs-konya-report" — 2012/3/1 — 18:29 — page } 211 \text { — \#7 }
$$

- which is their opinion about learning mathematics precisely the beauty and the difficulties of it.

Commensalism between board games and teaching maths

$$
\begin{gathered}
\text { Monika Dillingerová } \\
\text { Comenius University, Bratislava, Slovakia } \\
\text { E-mail: dillingerova@fmph.uniba.sk }
\end{gathered}
$$

If you ask someone to name some board games, probably you will hear titles like "Človeče, nehnevaj sa" (Pachisi), Monopoly, "Dostihy a sázky" (no English distribution or name known), Risk and a few others. But nowadays a new form of board game named "Euro" is becoming very popular. Euro games are well suited to use in schools. They require and utilize skills, they stimulate ways of thinking and they don't last too long. The board games bring cooperative learning, social interaction, and what never should be forgotten, fun into your lessons. In the article we show mathematic skills evolved by playing games, we make proposals, how to use them on regular math lessons.

The way to get the linear function from a physical example

$$
\text { Ottó Éder - Anna Soós }
$$

Babeş-Bolyai University, Faculty of Mathematics and Informatics, Cluj Napoca,

$$
\text { Romania }
$$

E-mail: edero@math.ubbcluj.ro, asoos@math.bbcluj.ro

The Rumanian mathematical education is very far from practical examples. The students get theoretical knowledge, but they don't know how to apply them. The inquired based learning method gives a new way to start with practical example and to get the theoretical notion. Our work contents two examples to start from physical examples [the length changing of the arc and the velocity of a walking person] and to arrive to the mathematical definition of the linear function. 


$$
\text { "tmcs-konya-report" — 2012/3/1 — 18:29 — page } 212 \text { — \#8 }
$$

Developing number sense in the first grade of the Hungarian primary education

Aranka Engbersen

University of Debrecen, Institute of Mathematics, Debrecen, Hungary

E-mail: engbersen@hotmail.com

"I do not like maths." - students often state. Spending more attention on developing our existing number sense in early elementary education could help pupils to understand better and get attached to mathematics and see it as sense making activity.

New opportunities in the use of homework problems

\section{Zoltán Fehér}

Selye János University, Komárno, Slovakia

E-mail: feherz@selyeuni.sk

The application of homework problems is traditionally a part of mathematics education. In higher education the use of homework is also important; in addition one can take advantage of the opportunities offered by ICT. The WeBWorK online homework system adds new features and enhances the educational process in several ways. Based on our experiences we can state that WeBWorK supports learning activities, encourages self-activity of students. It can be successfully used to support and control the continuous preparation of students.

\section{Experiences on WebAssign \\ Péter Fejes Tóth}

Corvinus University of Budapest, Faculty of Horticultural Science, Budapest,

\section{Hungary}

E-mail: fejestothpeter@yahoo.com

In October 2011 I collected data in the American International School of Budapest on the "WebAssign" - the homework solver online program they use. I asked the students to fill out a survey about their habits, experiences and opinion about WebAssign, and had several structured interviews with teachers about the program. I will also receive data about the students' grades and what the results of the homework sets which they did with WebAssign were. In my presentation I will introduce the observations I made, and part of the results of the survey that I have come into so far. 


$$
\text { "tmcs-konya-report" — 2012/3/1 — 18:29 — page } 213 \text { — \#9 }
$$

Researches in Didactics of Mathematics and Computer Sciences

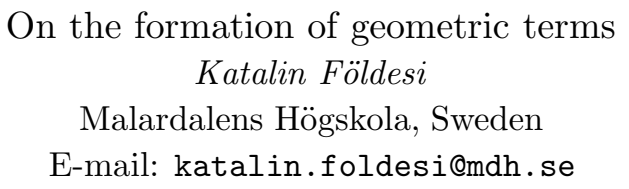

During the past few decades, in many countries, the teaching of geometry has been pushed into the background. In spite of this, there is a recurring demand for research into new ways to teach geometry and shape the materials used. One widely spread theory for teaching geometry was developed in the 1950s by the Dutch Van Hieles. It gives a wide range of possibilities for teaching geometry in a modern way. The theory uses five levels to categorize a student's level of thinking in Euclidean geometry. With the aid of this theory, Usischkin and his colleagues developed in the 1970s a short test which allows for the quick assessment of a student's Van Hiele level. I have run this test on several hundred Swedish college students, a small group of people consisting mainly of math teachers and I have received the results of two groups of Hungarian student teachers. I would like to present my findings on the outcome of these tests, the analysis of the test questions as well as how I used the results in my own teaching.

\section{E-learning and development of electronic teaching aids Viola Gazdiková \\ Catholic University of Ruzemberok, Ruzemberok, Slovakia E-mail: viola.gazdikova@ku.sk}

The employ ICT in educational is not only fashion trend, but it is necessity of society for rationalization educational process. New technology offer new possibilities for improvement of educational process. Using ICT in educational is the priority mainly in sphere of university educational and the lifelong educational in Slovakia. The article describes abilities and practical realization of implementation ICT for teaching and also a reason, how to achieve a need for reaching ICT competences in scientific. It offers a resource for special personal assurance of educational institutions, for abilities of ICT exploitation in educational process by CBT, but also for needs of e-learning. E-learning is important for university education and for continuing education too. We can use the technology (ICT) in the primary and secondary schools no only like teaching aids. We can use the technology like educational environment (e-learning). Great attention is spent for preparation teachers for using ICT in their practice. There are two preconditions for the use of ICT in education.

1. Technology preconditions, 


$$
\text { "tmcs-konya-report" — 2012/3/1 — 18:29 — page } 214 \text { — \#10 }
$$

2. Pedagogical assumptions (basic competences in ICT sphere which are necessary in pedagogical practice).

It's well known, there are two levels of competences:

- Competences needed for studies at university, which include effectiveness of study for students - ICT competences, which have wider validity, not only for students, who study education system.

- Competences, which a future teacher needs for his future occupation as a teacher - These competences are closely specialized for needs of teacher's occupation.

Students and teachers can acquire knowledge in electronic educational sphere with preparation of electronic educational materials. In the following we explain the basic structure of e-books and applications for their development.

\section{CLIL method in the Slovak mathematics education at Slovak minority school in Hungary Ján Gunčaga}

Catholic University of Ružemberok, Faculty of Pedagogy, Ružemberok, Slovakia E-mail: jan.guncaga@ku.sk

We present in the beginning some theoretical approaches for Content and Language Integrated Learning as a tool for teaching of minority language. This method is recommended by European Union for preparing of minority teachers and in the teaching process. We present some concrete examples from mathematics education and research, which we will start.

Activities in the preparation for the concept of area Eszter Herendiné Kónya - Margit Tarcsi

Debrecen Reformed Theological University, Kölcsey Institute of Primary Education, Debrecen, Hungary

E-mail: hke@kfrtkf.hu, tarcsim@kfrtkf.hu

At the beginning of the teaching of the concept of area we focused on various activities. The tiling is emphasized particularly with congruent patterns. We make a distinction between tiling in plane and tiling polygons of a given area. Special attention has been paid to the development of the skill of estimation during the covering of the tiles, namely what kind of patterns are suitable for tiling the polygons on the on hand, and how many tiles from the selected patterns are needed to cover the polygons on the other. These activities were carried out 
in classes 4., 5., and 6. Our observations and experience are summed up in the talk.

Concept of the mass like a physical quantity in elementary school

$$
\text { László Jaruska }
$$

Selye János University, Komárno, Slovakia

E-mail: jaruskal@selyeuni.sk

The introduction of physical units and quantities is an important element of science elementary education. Our students learn units of time, length, mass, volume, temperature and force. Various educational projects differ in their approach to the topic as well as in grade in which the units are introduced. In the contribution, we will try to show the concept formation especially the formation of mass. The mass belong to most cardinal quantities of the physics. Our student meets with it during the mathematics and science elementary education. Students work with it systematically, therefore it is necessary to give increased attention to the introduction.

Digital competence and it's impact on student performance results (Analytical comparison of digital competence within Slovak, Czech and Irish Mathematics)

Stanislav Javorský

University of Trnava, Trnava, Slovakia

E-mail: stanislav.javorsky@truni.sk

Actual social and commercial situation comes across as recessive. One of spheres directly influencing this condition is an educational sphere and vice versa unflattering decadence manipulates the sphere of education. Important part is to determine such relevant limits and stimuli correctly which cause quality of its system. Focus on digital competence content as one of stimuli participates and offers the ways for knowledge level increase and development of student capabilities within specific educational disciplines (Gazdíková, 2010). By analysis of explicitly-defined capabilities reflecting the focus of digital competence within a comparison of selected European countries; we reflect a cross-sectional perspective on contentual disproportion of capabilities regarding to digital competence. Reciprocally analysis presents relative contentual interference from the point of educational policies of analyzed nations. 


$$
\text { "tmcs-konya-report" — 2012/3/1 — 18:29 — page 216 — \#12 }
$$

About J. Egerváry who established the so-called Hungarian method Tünde Kántor

University of Debrecen, Institute of Mathematics, Debrecen, Hungary

E-mail: tkantor@science.unideb.hu

J. Egerváry (1891-1958) was an outstanding mathematician academic and Kossuth-prize winner.

He was born in Debrecen. He went to the famous Fazekas secondary school of the town. These roots accompanied him in his life and work. The characteristics of his activity were clarity, accuracy, preferring visualisation and applications of theoretical scientific results in the practice.

He took care of talented students, he developed their mathematical thinking. He proposed a lot of problems for mathematical competitions and published their solutions too. For a long time his personality was a model of younger mathematicians.

His most important mathematical results belong to the theory of matrices. He proved a theorem of D. König of the theory of graphs, using methods of the theory of matrices. He found a simple way of solution of ordering and transporting problems.

This method was named by W. Kuhn (USA) as the Hungarian method.

Teaching the applications of differentiation and integration with

\section{GeoGebra}

\section{Anna Klingné Takács}

Kaposvár University, Faculty of Economic Science, Kaposvár, Hungary

E-mail: klingne.anna@ke.hu

We announced an optional course for our students at Kaposvár University, where computerised methods are used to teach and learn Calculus. At first it was only Excel which helped students to observe the properties of sequences and functions and to determine limits. As we are getting acquainted with GeoGebra, it is drawn into the courses at more and more areas, such as the applications of differentiation and integration. Our students often use the program at home learning to check the accuracy of the problems they have solved. They can do function analysis with the latest version of the program, its mathematical symbol set appears in the familiar form. We show how GeoGebra applications are inserted in the teaching-learning process of our BSc students of Economic Science. 


$$
\text { "tmcs-konya-report" — 2012/3/1 — 18:29 — page } 217 \text { — \#13 }
$$

Researches in Didactics of Mathematics and Computer Sciences

Questions of teaching mathematics in technical higher education Imre Kocsis

University of Debrecen, Faculty of Engineering, Debrecen, Hungary

E-mail: kocsisi@eng.unideb.hu

Teaching mathematics for engineering students in technical higher education we have to face significant difficulties and some problems go back a long time. This situation can be considered as a problem of the education system or of the teaching methodology, as well. In this talk the following questions will be discussed: What is our aim during the teaching process? What does the curriculum depend on? What does the teaching method depend on? And generally: Is our system suitable to reflect on the problems of students and to meet the requirements?

The role of knowledge acquired in secondary school in higher education

$$
\text { Judit Kollár }
$$

Budapest Buisness School, College of Finance and Accountancy, Budapest,

$$
\text { Hungary }
$$

E-mail: zolna1@freemail.hu

We have been witnessing more and more depressing results concerning the abilities of students joining higher education lately. Their knowledge of mathematics is worse than it used to be, and it is not sufficient to support a successful professional training. The results of mathematics tests carried out among college freshmen reflect a decisive contribution of the knowledge acquired in secondary education to the success of students in higher education.

We are posing questions and forming the hypotheses for our proposed research in this talk.

Mathematics and Mathematicians in the Media

$$
\text { József Korándi }
$$

Eötvös Lorand University, Mathematics Teaching and Education Centre,

Budapest, Hungary

E-mail: korandi@cs.elte.hu

My research topic is finding connection between mathematics and media. First of all, I am engaged with studying the image of mathematics, mathematicians and mathematical content as it appears in the popular media. In my presentation I am going to analyze a few shots from a movie picture. In this movie, though as a scenic element only, correct mathematical content shows up. In the 


$$
\text { "tmcs-konya-report" — 2012/3/1 — 18:29 — page 218 — \#14 }
$$

presentation I will primary and secondary school and university level mathematical content, one of each kind, from the movie which is suitable to develop the mathematical competence of the learners.

\section{Mathematics on the Internet Balázs Koren \\ Budai High School, Budapest, Hungary \\ E-mail: balazs.koren@gmail.com}

For our students posting on the Facebook wall feels more natural than writing in pen and pencil in their exercise books. Can we make mathematics so exciting, too? Is it possible to get our pupils' attention using these new platforms? Smartphones, tablets, Internet, etc. How do we involve these new technologies in our everyday teaching?

I would like to show some practical working examples, modelling tasks using ICT, different ways how we can use the Internet and special mathematics education softwares, like GeoGebra.

Various usage possibilities of e-tests in mathematical digital environment on secondary schools

\section{Lilla Koreñová}

Comenius University, Bratislava, Slovakia

E-mail: korenova@fmph.uniba.sk

Didactic tests as we know them serve for determining the quality and the quantity of the students' knowledge. The creation and evaluation of didactic tests are in the focus of special theories. Digital technology has brought and created electronic aids (hardware and software) for testing students. These aids have further possibilities of usage in the education process such as motivation, repetition, exercising, and evaluation. They can also be used in new teaching methods such as controlled discovering. The goal of this paper is to show various possibilities of using the free software HotPotatoes and GeoGebra in didactic situations in teaching mathematics on high schools. 


$$
\text { "tmcs-konya-report" — 2012/3/1 — 18:29 — page } 219 \text { — \#15 }
$$

\section{On Development of the Problem Solving Abilities József Kosztolányi \\ University of Szeged, Bolyai Institute, Szeged, Hungary \\ E-mail: kosztola@math.u-szeged.hu}

"What the teacher says in the classroom is not unimportant, but what the students think is a thousand times more important. The ideas should be born in the student's mind and the teacher should act only as midwife. ... the principle is: let the students discover by themselves as much as feasible under the given circumstances." (G. Pólya)

I strongly believe, and my observations back up this idea that guided discovery can be used at all levels of teaching mathematics. Though this method is linked to problem solving in my lecture, I still think that acquiring new materials (concepts, definitions, theorems, proofs, algorithms) is more effective for the students' part if it is discovered by themselves either to some degree or on the whole. I will illustrate this method with actual examples in the course of the lecture.

Introducing computer technology into mathematics teacher training Zoltán Kovács College of Nyíregyháza, Nyíregyháza, Hungary

E-mail: kovacsz@nyf .hu

Technology should be an integral part of teacher preparation programmes. Computer aided mathematics teaching was included in the Hungarian curriculum of mathematics teacher training recently. As the main perspective, students must develop competence to decide when and how it is appropriate to use available ICT tools. To meet this demand we developed a course "Computer aided mathematics teaching." In the paper I present the course design, and evaluate experiences.

On a quality assurance model for computer aided teaching Anna Kozárné Fazekas

Kossuth Lajos Secondary School, Debrecen, Hungary

E-mail: kfanna@gmail.com

Ever since their introduction in the late eighties of the previous century the ISO 9000 standards have resulted in a revolution in the quality assurance issues. Because of their wide range of applicability, today almost half a billion organizations have adopted these standards. However, relatively few educational institutions, and even fewer secondary schools are registered worldwide. This can be partly due to the complexity and difficulty of the "product of education", 


$$
\text { "tmcs-konya-report" — 2012/3/1 — 18:29 — page } 220 \text { — \#16 }
$$

i.e. the graduated students and pupils. Another problem can be the lack of clearly defined quantitative tools for measuring the performance of education and establishing the most effective feedback processes.

In this paper, following the pioneer SQC based ideas of S. Karapetrovic we present a possible adaptation of SQC for secondary school language teaching. We believe that these ideas can be applied in the teaching of many other subjects. Computers play a very important role in the realization.

\section{Modelling hypercomplex numbers \\ Péter Körtesi \\ University of Miskolc, Miskolc, Hungary \\ E-mail: matkp@uni-miskolc.hu}

Kantor and Solodovnikov introduced hypercomplex numers as finite dimensional algebras over the reals int he following way:

$$
H=\left\{a_{0}+a_{1} i_{1}+a_{2} i_{2}+\ldots+a_{n} i_{n} \mid a_{0}, a_{1}, a_{2}, \ldots, a_{n} \in P \text { and } i_{k}^{2} \in\{-1,0,1\}\right\}
$$

So for $n=1$ we will have beside the complex numbers:

$$
X=\left\{a+b i \mid a, b \in \mathbb{R}, i^{2}=-1\right\},
$$

two other sets:

The hyperbolic complex numbers: $\Sigma=\left\{a+b E \mid a, b \in \mathbb{R}, E^{2}=1\right\}$ and the dual-complex numbers $\Delta=\left\{a+b \Omega \mid a, b \in \mathbb{R}, \Omega^{2}=0\right\}$.

We have to remark, that the latter two sets are not commutative fields, but associative algebras, in fact they aren't even division algebras.

We can study them by $2 \times 2$ matrix modells, similarly to complex numbers, moreover this models are suitable for studying the quaternions obtained by the Cayley-Dickson doubling from complex numbers, and for other four dimensional hypercomplex numbers as well.

\section{Kvizy \\ Edit Lázár}

University of Debrecen, Faculty of Informatics, Debrecen, Hungary

E-mail: ledit4@hotmail.com

On the way of Maths didactic a program was born. It called Kvizy.

In my conference I want to show my program developing with examples.

Teaching I saw that for teachers and students is problem how to (make) practice and how to do a test/questionnaire. So I am doing a dynamic homepage with PHP and MySQL. 


$$
\text { "tmcs-konya-report" — 2012/3/1 — 18:29 — page } 221 \text { — \#17 }
$$

You as user can choose what you want to do: a test or an exam. You have to give the topic and the number of questions. The program generates a test and when you finish you can send or reset it. At the background of this there is a Maths database by MySQL. The main table of this is the Question table with fields as Question, Right answer, Bad answer1-10 and various IDs, too. After terminating this part I am going to prepare a complement to the page with animated and detailed solution description.

Changes of content in the mathematics courses offered at the College of Finance and Accountancy and at the Budapest Business School Sándor Molnár

Budapest Buisness School, College of Finance and Accountancy, Budapest, Hungary

E-mail: Molnar.Sandor@pszfb.bgf .hu

The number of class meetings increased significantly in mathematics courses at the College of Finance and Accountancy in 1972. Later, paralleling with a jump in the number of students the number of class meetings decreased. The decrease in the number of class meetings forced the reduction of the content of the courses and the streamlining of the schedule. A peculiar student behaviour: 'utilizing the benefits of the credit system' emerged. The introduction of the Bologna System met the disapproval of most of the faculty. We speak of our present problems in this talk. It turns out that these problems, though related to, are not direct consequences of the Bologna system.

Teaching of basic knowledge of natural sciences at University of Debrecen Rita Nagyné Kondor - Gusztáv Áron Sziki

University of Debrecen, Faculty of Engineering, Debrecen, Hungary

E-mail: kondorri@freemail.hu, szikig@eng.unideb.hu

On the basis of our experience at the Faculty of Engineering, University of Debrecen, the high number of engineering students who fail to meet the requirements of the different foundation and special subjects can be explained by their insufficient basic knowledge in mathematics and physics. To handle the problem from the first semester of the 2009/10 academic year we introduced a compulsory subject "Basic Knowledge of Natural Sciences". The aim of this subject is to summarise and repeat those parts of elementary and secondary school mathematics, geometry and physics which are necessary as basic knowledge at our Faculty. In 


$$
\text { "tmcs-konya-report" — 2012/3/1 — 18:29 — page } 222 \text { — \#18 }
$$

the following we present our experiences about the introduction and instruction of this subject.

The appearance of mathematical competencies in the students' solution Ilona Oláhné Téglási

Eszterházy Károly College, Faculty of Mathematics and Informatics, Eger,

Hungary

E-mail: olahneti@ektf.hu

The aim of competence based mathematics teaching is to develop the students' mathematical skills and abilities. This should be achieved during the teaching of the curriculum through adequate exercises: motivating, interesting, practical problems that fits into the teaching matter. I would like to show how the elements of mathematical competencies appear, and can be detected through analyzing some exercises solved by students. Such an analysis can give important information to the teacher about the state of the student's abilities and the areas of development. I'd like to make a methodological material, which can help teachers with the analysis.

\section{Mathematics for primary school teachers Edita Partová \\ Selye János University, Komárno, Slovakia \\ E-mail: partova@gmail.com}

Discussion of problem which mathematics knowledge are important for teachers at primary level take several years already, but the concept "Knowing Mathematics for Teaching" appears after Shulman's introduction of the notion of "Pedagogical Content Knowledge". Resent research focuses on conceptualization Mathematical Knowledge for Teaching (MKT) and its measurement. Difference between knowledge for mathematicians, common people and teachers is the subject of our research realised in cooperation with Central Michigen University. We assume that findings of this project will support effectively of teacher education involving measuring it outcomes. 
"tmcs-konya-report" — 2012/3/1 — 18:29 — page 223 — \#19

Researches in Didactics of Mathematics and Computer Sciences

Practical application of informatics in teaching colour dynamics to students of civil engineering

Erika Perge

University of Debrecen, Faculty of Engineering, Debrecen, Hungary

E-mail: perge@ang.unideb.hu

Using electronic devices and computer software has created brand new ways of acquiring and conveying information. My aim is to demonstrate how to apply various electronic tools effectively in the process of teaching and learning colour theory, as well as cultivating students' ability to recognize, distinguish and define colours. My lecture offers a brief overview on colour theory as taught to students on different levels of education, pointing out flaws in the existing education system. It also demonstrates the results of a survey aiming to assess the level of understanding of colour theory among new students beginning their studies at the Faculty of Civil Engineering, University of Debrecen.

The use of multimedia in the context of e-exams Jacek Stańdo - Konrad Szumigaj

Technical University of Lodz, Poland

E-mail: jacek.stando@p.lodz.pl

For several years in Poland are sample exams by Iternet. Differences between the traditional examination and the e-exam are a lot. One of them is able to use the e-exam for the construction of multimedia tasks. The article will present some examples of multimedia applications for the construction tasks, and we discuss their meaning.

Specialty of probability thinking - decisions and eruditions Judit Szitányi

Eötvös Loránd University, Faculty of Primary and Pre-school Education, Budapest, Hungary

E-mail: szitanyi.judit@gmail.com

During my research I looked for the answer to the question of the difference between the probability decisions and estimations and thinking strategies applied to other areas of mathematics. With this object, I made measurements in the last couple of years, in which I compared thinking of elementary teacher candidates and students learning mathematics or other natural sciences at university of ELTE. I was curious to know that how much the interest of mathematics influences the probability decisions. 


$$
\text { "tmcs-konya-report" — 2012/3/1 — 18:29 — page } 224 \text { — \#20 }
$$

This comparison led to interesting results in several occasions inspiring me to repeat my research with pupil in elementary school. On this way, I tried to figure it out how deeply the studies of probabilities have been integrated into thinking of graduated people.

I would like to summarize my new experiences now. I am going to outline the sameness and differences in probability thinking of people graduated or not in mathematics

Attitudes of pupils and teachers as important factor for mathematics education

Peter Vankúš - Emilia Kubicová

Comenius University, Bratislava, Slovakia

E-mail: peter.vankus@gmail.com

The contribution deals with pupils' attitudes towards mathematics, their structure and changes between the fifth and the ninth grade of primary school. We discuss statistically significant factors influencing the attitudes towards mathematics and the impact on the education. Important factor is the teacher and the teaching - learning styles. Therefore, in the paper we discuss also teachers' attitudes and their influence on the education.

The understanding of the meaning of continuous functions and differential through the support of the software GeoGebra

$$
\text { Ferenc Várady }
$$

Budapest Buisness School, College of Commerce, Catering and Tourism,

$$
\text { Budapest, Hungary }
$$

E-mail: varadyf@gmail.com

As a college teacher I can often see that since students first meet the mathematical definitions and theorems very abstractly at the lectures, they are not able to understand their deeper meaning in the seminars either. Better and hardworking students can learn the necessary way of problem solving, but they cannot or can just partly understand its mathematical meaning. Thus they only use a mechanical algorithm to solve mathematical problems, the result of which is, as they do not understand their fundaments that they forget the method of solution rapidly, and they cannot solve even a slightly different problem. Therefore they cannot understand and solve problems which are based on this essential knowledge. A lot of psychological research proves what important role visual and symbolic representations have in the learning process. In my lecture I try to 
show the relation between the symbolic and the visual meaning by the definition of continuous function and by the differential and the slope of the tangent line. Thus students can better understand the contact between theory and the meaning behind it. I try to bridge this gap with the visual advantage of the software GeoGebra, supporting the understanding of students and deepening the curriculum at the same time.

On modern Trends in international Mathematics Education and some neglected Research Domains

Bernd Zimmermann

Friedrich-Schiller-University of Jena, Department of Mathematics and Computer Science Education, Jena Germany

E-mail: pertti1@gmx.de

Approaches to mathematics education have to cope with possible answers to questions as follows:

- What is mathematics?

- What kind/part of mathematics my students should learn and why?

- How to teach mathematics?

- How students learn mathematics?

- What picture of human beeing might be/should be appropriate?

- How to determine the results of teaching and learning?

- How to justify your own approach?

Referring to these questions, we will present first some traditional approaches to mathematics education as the socratic method, the structuralistic/formalistic approach ("New Math"); the genetic approach, the approach by braking up mathematics into small pieces (hopefully) to be learned more easy.

Modern approaches to mathematics education focus on

- the utility-aspect of mathematics (application of mathematics in real life),

- the autonomy of the learner,

- less guidance by the teacher by applying a varity of modern teaching methods as group and project work,

- the use of modern technology as computers and internet,

- modern learning theories as constructivism and the interplay of conceptual and procedural learning,

- output-orientation. 


$$
\text { "tmcs-konya-report" — 2012/3/1 — 18:29 — page 226 — \#22 }
$$

We will discuss possible reasons for focussing on these aspects, possible differences to traditional approaches as well as possible advantages and limits.

Finally we give an outlook to neglected research domains as

- effective implementation of latest results of research into praxis

- possible relation between learning outcome, use of modern technology and quality of teaching.

Teaching probability using graph representations Gabriella Zsombori

Sapientia Hungarian University of Transylvania, Faculty of Economic and Human Sciences, Miercurea-Ciuc, Romania

E-mail: zsomborigabriella@gmail.com

This paper has two main objectives. The first is to present an elementary approach to classical probability theory, based on graph representation and counting techniques, highly suitable for teaching in lower and upper secondary schools. The second aim is to report about teaching experiences on different levels (lower secondary school, upper secondary school, high school, teacher training, professional development, university) based on this approach. The basic idea of this approach is to reduce the calculations and the probability properties to counting paths in trees. In this way the probability, the conditional probability and the classical probability models can be treated in a unique manner, which can eliminate a big part of the experienced difficulties and problems that appear in the teaching of elementary probability. The experiences related to the teaching aspects confirms the usefulness of this approach at all tested levels (from lower secondary school to university level), moreover they show that this approach can be used before (and in order to prepare) the classical set theoretic approach of classical probability theory. The main strength of the representations is that they contain the structure of the calculations at counting level; hence most of the common mistakes can be eliminated.

\section{List of participants}

1) András Ambrus, Eötvös L. University, Mathematics Teaching and Education Centre, Budapest, Hungary, ambrus@cs.elte.hu

2) Szilárd András, Babeş-Bolyai University, Faculty of Mathematics and Informatics, Cluj-Napoca, Romania andraszk@yahoo.com 
3) Viktor Bakos, Budapest Business School, College of International Management and Business, Budapest, Hungary, Bakos.Viktor@kkfk.bgf .hu

4) Tünde Baranyai, Babeş-Bolyai University, Faculty of Psychology and Educational Sciences, Satu Mare, Romania, baratun@yahoo.com

5) Krisztina Barczi, Neumann János High School, Eger, Hungary, bkrixta@gmail.com

6) Csaba Bíró, Eszterházy Károly College, Eger, Hungary, birocs@aries.ektf .hu

7) Judit Boda, University of Debrecen, Institute of Earth Sciences, Debrecen, Hungary, boda.judit@science.unideb.hu

8) Ignác Bontovics, Szent István University, Faculty of Applied Arts and Pedagogy, Szarvas, Hungary, bignacz@gmail.com

9) László Budai, II. Rákóczi Ferenc Secondary School, Szécsény, Hungary, budai0912@gmail.com

10) Anikó Csákány, Budapest University of Technology and Economics, Institute of Mathematics, Budapest, Hungary, csakany@math.bme.hu

11) Edith Debrenti, Partium Christian University, Oradea, Romania, edit.debrenti@gmail.com

12) Monika Dillingerová, Comenius University, Bratislava, Slovakia, dillingerova@fmph. uniba.sk

13) Ottó Éder, Babeş-Bolyai University, Faculty of Mathematics and Informatics, Cluj Napoca, Romania, edero@math.ubbcluj.ro

14) Aranka Engbersen, University of Debrecen, Institute of Mathematics, Debrecen, Hungary, engbersen@hotmail.com

15) Gábor Fazekas, University of Debrecen, Faculty of Informatics, Debrecen, Hungary, fazekas.gabor@inf .unideb.hu

16) Zoltán Fehér, Selye János University, Komárno, Slovakia, feherz@selyeuni.sk

17) Péter Fejes Tóth, Corvinus University of Budapest, Faculty of Horticultural Science, Budapest, Hungary, fejestothpeter@yahoo.com

18) Edit Földesi, BÉKSZI, f.ditti@vipmail.hu

19) Katalin Földesi, Malardalens Högskola, Sweden, katalin.foldesi@mdh.se

20) István Füvesi, University of Szeged, Department of Informatics, Szeged, Hungary, fuvesi@inf.u-szeged.hu 
21) Viola Gazdíková, Catholic University of Ružemberok, Ružemberok, Slovakia, viola.gazdikova@ku.sk

22) Gábor Geda, Eszterházy Károly College, Institute of Mathematics and Informatics, Eger, Hungary, gedag@aries .ektf.hu

23) Ján Gunčaga, Catholic University in Ružomberok, Faculty of Pedagogy, Ružomberok, Slovakia, jan.guncaga@ku.sk

24) Eszter Herendiné Kónya, Debrecen Reformed Theological University, Kölcsey Institute of Primary Education, Debrecen, Hungary, hke@kfrtkf .hu

25) László Jaruska, Selye János University, Komárno, Slovakia, jaruskal@selyeuni.sk

26) Stanislav Javorský, University of Trnava, Trnava, Slovakia, stanislav. javorsky@truni.sk

27) Tünde Kántor, University of Debrecen, Institute of Mathematics, Debrecen, Hungary, tkantor@science.unideb.hu

28) Csaba Kézi, University of Debrecen, Faculty of Engineering, Debrecen, Hungary, kezicsaba@science.unideb.hu

29) Anna Klingné Takács, Kaposvár University, Faculty of Economic Science, Kaposvár, Hungary, klingne. anna@ke.hu

30) Imre Kocsis, University of Debrecen, Faculty of Engineering, Debrecen, Hungary, kocsisi@eng.unideb.hu

31) Judit Kollár, Budapest Buisness School, College of Finance and Accountancy, Budapest, Hungary, zolna1@freemail.hu

32) József Korándi, Eötvös Lorand University, Mathematics Teaching and Education Centre, Budapest, Hungary, korandi@cs.elte.hu

33) Balázs Koren, Budai High School, Budapest, Hungary, balazs.koren@gmail.com

34) Lilla Koreňová, Comenius University, Bratislava, Slovakia, korenova@fmph.uniba.sk

35) József Kosztolányi, University of Szeged, Bolyai Institute, Szeged, Hungary, kosztola@math.u-szeged.hu

36) Zoltán Kovács, College of Nyíregyháza, Nyíregyháza, Hungary, kovacsz@nyf . hu

37) Anna Kozárné Fazekas, Kossuth Lajos Secondary School, Debrecen, Hungary, kfanna@gmail.com 


$$
\text { "tmcs-konya-report" — 2012/3/1 — 18:29 — page } 229 \text { — \#25 }
$$

38) Péter Körtesi, University of Miskolc, Miskolc, Hungary, matkp@uni-miskolc.hu

39) Gábor Kusper, Eszterházy Károly College, Institute of Mathematics and Informatics, Eger, Hungary

40) Károly Lajkó, College of Nyíregyháza, Nyíregyháza, Hungary, lajko@science.unideb.hu

41) Edit Lázár, University of Debrecen, Faculty of Informatics, Debrecen, Hungary, ledit4@hotmail.com

42) Margit Lénárd, College of Nyíregyháza, Nyíregyháza, Hungary

43) Gyula Maksa, University of Debrecen, Institute of Mathematics, Debrecen, Hungary, maksa@science.unideb.hu

44) Ilona Máté, The Lower-Secondary School of Paptamasi, Paptamasi, Romania, mateilona@yahoo.com

45) Sándor Molnár, Budapest Buisness School, College of Finance and Accountancy, Budapest, Hungary, Molnar.Sandor@pszfb.bgf .hu

46) Péter Nagy, Budapest Buisness School, University of Debrecen, Hungary, petert.nagy@science.unideb.hu

47) Rita Nagyné Kondor, University of Debrecen, Faculty of Engineering, Debrecen, Hungary, kondorri@freemail.hu

48) Ilona Oláhné Téglási, Eszterházy Károly College, Faculty of Mathematics and Informatics, Eger, Hungary, olahneti@ektf .hu

49) Zsolt Páles, University of Debrecen, Institute of Mathematics, Debrecen, Hungary, pales@science.unideb.hu

50) Edita Partová, Selye János University, Komárno, Slovakia, partova@gmail.com

51) Erika Perge, University of Debrecen, Faculty of Engineering, Debrecen, Hungary, perge@ang.unideb.hu

52) Richárd Rakamazi, Neumann János High School, Eger, Hungary, raka82@gmail.com

53) Anna Soós, Babeş-Bolyai University, Faculty of Mathematics and Informatics, Cluj Napoca, Romania, asoos@math.bbcluj.ro

54) Jacek Stańdo, Technical University of Lodz, Poland, jacek.stando@p.lodz.pl 
"tmcs-konya-report" — 2012/3/1 — 18:29 — page 230 — \#26

55) Gusztáv Áron Szíki, University of Debrecen, Faculty of Engineering, Debrecen, Hungary, szikig@eng. unideb.hu

56) Judit Szitányi, Eötvös Loránd University, Faculty of Primary and Pre-school Education, Budapest, Hungary, szitanyi.judit@gmail.com

57) Konrad Szumigaj, Technical University of Lodz, Poland

58) Margit Tarcsi, Debrecen Reformed Theological University, Kölcsey Institute of Primary Education, Debrecen, Hungary, tarcsim@kfrtkf.hu

59) Štefan Tkačik, Catholic University of Ruzemberok, Ruzemberok, Slovakia, tkacik@ku.sk

60) Judit T. Nagy, Edutus College, Budapest, Hungary, tnagy.judit@gmail.com

61) Peter Vankúš, Comenius University, Bratislava, Slovakia, peter.vankus@ gmail.com

62) Ferenc Várady, Budapest Buisness School, College of Commerce, Catering and Tourism, Budapest, Hungary, varadyf@gmail.com

63) Magda Várterész, University of Debrecen, Faculty of Informatics, Debrecen, Hungary, varteresz.magda@inf .unideb.hu

64) Bernd Zimmermann, Friedrich-Schiller-University of Jena, Department of Mathematics and Computer Science Education, Jena Germany,

pertti1@gmx.de

65) Gabriella Zsombori, Sapientia Hungarian University of Transylvania, Faculty of Economic and Human Sciences, Miercurea-Ciuc, Romania, zsomborigabriella@gmail.com

ESZTER HERENDINÉ KÓNYA

DEBRECEN REFORMED THEOLOGICAL UNIVERSITY

KÖLCSEY INSTITUTE OF PRIMARY EDUCATION

PÉTERFIA STR. 1-7.

DEBRECEN

HUNGARY

H4026

E-mail: hke@kfrtkf.hu

(Received February, 2012) 